\title{
Changes in water resources in selected lakes in the middle and lower catchment of the River Warta
}

\author{
Mariusz Ptak ${ }^{1}$, Agnieszka E. Ławniczak ${ }^{2}$ \\ ${ }^{2}$ Institute of Physical Geography and Environmental Planning, Adam Mickiewicz University, Dzięgielowa 27, 61-680 Poznań, Poland; \\ e-mail:marp114@wp.pl \\ ${ }^{2}$ Department of Ecology and Environmental Protection, Poznan University of Life Sciences, Piątkowska 94C, 60-649 Poznań, Poland; \\ e-mail: lawnic@up.poznan.pl
}

\begin{abstract}
Lakes play a very important function in water retention, particularly in areas with strong water deficiency. Water resources in lakes determine the possibility of using them for different purposes, e.g. economic development (irrigation or drinking water, water supply for industry). With ongoing processes causing a reduction in lake capacity (shrinking and shallowing), it is necessary to investigate the scale and rate of decreasing lake resources, in terms of the economic and natural consequences of this process. The aim of the study was to test changes in water resources in lakes situated in the middle and lower River Warta catchment. Special attention was paid to lakes characterised by reduced water resources in order to identify factors contributing to this phenomenon. Our current studies of 127 lakes showed a $10 \%$ decrease in water resources over 50 years (1910-1960) in the analysed part of the catchment. Our results indicated that the predominant process causing the disappearance of lakes is shallowing. This factor should be monitored carefully to avoid further lake loss.
\end{abstract}

Key words: lake disappearance, shallowing, shrinking

\section{Introduction}

Lakes are a crucial link in the water cycle. One of the important roles of lakes is their water retention capabilities. This is very important in regions where water deficiency is serious and occurs more frequently. Water shortage often occurs due to improper management of the environment, e.g. drainage of wetlands, deforestation, etc.

In Europe, river regulation and agricultural use of rivers and lake floodplains have had a large impact on the dwindling of lakes (Müller et al. 1998; van Puijenbroek et al. 2004; Choiński and Ptak 2009). The disappearance of hydrodynamic gradients due to the construction of dykes, weirs and other flood defence measures or predominantly due to dams' and levees' constrictions caused the degradation of lakes. Changing land use in lake basins related to urbanisation and impermeabilisation, drainage of agricultural fields, river regulations and reduction in the size of active floodplains are the primary cause of increasing discharge quantities and they also enhance extreme flood events (Pfister et al. 2004; Antheunisse 2007). A large amount of rainfall in lake basins supports massive discharge into lakes and sustains a strong basin effect on lake levels and water quality (Hu et al. 2007). Excluding eutrophication, which is recognised as the major factor driving lake disappearance, lakes in mountain areas show rapid filling due to natural processes such as avalanche occurrence (Choiński and Ptak 2009), water supply from glaciers or snow accumulation, and cyclical modifications in the evapotranspiration regime (Pasquini et al. 2008). In Poland, lake disappearance is most pronounced in agricultural areas. A good example of changes caused by intensive land use is seen in a large part of the Wielkopolsko-Kujawskie Lakeland.

Unfortunately, the water retention capacity of lakes changes due to the influence of such factors as shallowing and shrinking. Permanent interactions between these processes may, in the near future, prevent the use of lake water resources for economic purposes, i.e. irrigation, filling ponds. Continued lake use accompanied by simultaneous shrinkage of the water volume can accelerate the exhaustion of inviolable resources necessary for the lake functioning. 
Most studies focusing on changes in water resources in Poland deal with the assessment of lake size (Majdanowski 1954; Mikulski 1965; Jańczak 1984; Choiński 1988) and are based on analyses of individual lakes or groups of several (a maximum of one dozen) lakes (Choiński 2002, 2007; Choiński and Ptak 2009; Ławniczak et al. 2011). Investigations and studies including a higher number of lakes are essential. Recognition of the major processes triggering lake disappearance and the rate of their loss is crucial for proper management and protection of lake ecosystems.

The aim of the study was to test changes in water resources in lakes situated in the middle and lower River Warta catchment. Special attention was paid to lakes characterised by reduced water resources in order to identify factors contributing to this phenomenon.

\section{Material and methods}

Comparative analyses were applied based on materials from the beginning of the 20th century (Schütze 1920; KJP 1954) and from the beginning of the 1960s (Choiński 2006). In total, 127 lakes from the middle and lower part of the Warta catchment were selected. Table 1 presents the surface area, volume and latitude of the studied lakes within two periods. The final number of chosen lakes depended on available data from both periods. The first sources of data came from investigations carried out by Germen researchers from 1904-1916 (Schütze 1920; KJP 1954). The second set of data came from the Institute of Inland Fisheries in Olsztyn and were based on investigations carried out in the 1950s and 1960s (Choiński 2006).

The database from the initial period of studies was designated here as 1910 and the database from the second period was designated as 1960 .

\section{Results}

During the first study period (1910), total lake surface was 25304.6 ha (assumed as 100\%) and the volume was estimated at $2310.9 \mathrm{hm}^{3}$ (assumed as $100 \%)$. In the second study period, the lake surface amounted to 23736.0 ha and the volume was 2079.9 $\mathrm{hm}^{3}$. It is evident that during the period of 50 years the surface area of the studied lakes decreased by $6.2 \%$ and their volume by $10 \%$ (Fig. 1 ).

Of the 127 lakes examined, water resource reduction was observed in 93 reservoirs $(73.2 \%$ of the total number of lakes). The highest decrease in lake

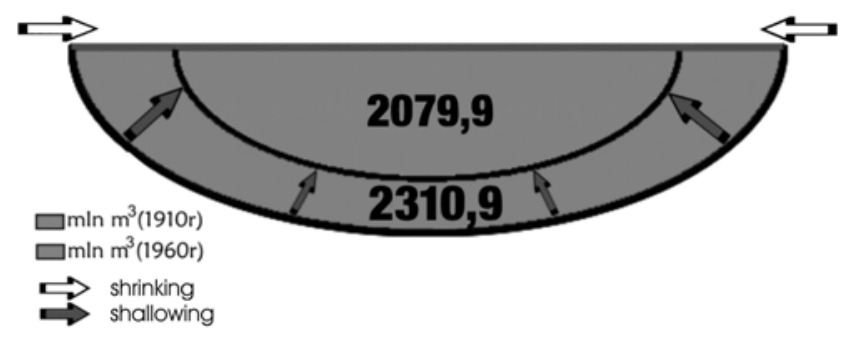

Fig.1. Schematic diagram of direction of water resources reduction

capacity amounting to $47.8 \%$ and $44.6 \%$ was detected in Prostynia and Stępińskie lakes, respectively.

In comparison with the beginning of the 20th century, 19 lakes increased their retention by almost one fourth. The water capacity of 10 of the studied lakes did not change. In 24 lakes an increase in water resources was detected. The most significant increases in water resources was detected in Lake Piechiewo (over 150\%) and Lake Małe (by 100\%).

In total over 50 years, lake surface was reduced by $6.2 \%$ and volume by $10 \%$. Analyses of water resources within groups of lakes based on surface area showed the most significant changes in the biggest lakes (100-500 ha) (Tab. 2). This group was represented by the highest number of lakes. The richest water resources were accumulated in the group of large lakes, where $30 \%$ of total water capacity was stored in four lakes. Unfortunately, all lakes from this group were characterised by a reduction in water resources of $9.9 \%$.

Table 3 presents the number of lakes within categories of their surface and water resource changes. The highest number of lakes is found in the group of lakes in which surface area declined by $0-25 \%$, which was accompanied by a similar simultaneous reduction in water resources. The next group of lakes includes the category characterised by a surface increase of $0-25 \%$, accompanied by a decrease in their volume by the same range.

This group as well as the two following groups (25-50 and more than 50) indicate that changes in water resources are influenced significantly not only by apparent shrinking processes but also by shallowing.

Continuous supply of material flowing in from the lake catchment, as well as from outside, together with biomass produced in the reservoir itself, lead to a permanent "lifting" of the bottom and this consequently decreases the capacity of the lake. Table 4 gives examples of lakes where shallowing is responsible for decreased water resources. 
Table 2. Changes in water resources within size classes of lakes

\begin{tabular}{|c|c|c|c|c|c|c|c|c|c|}
\hline \multicolumn{2}{|r|}{ Size class [ha] } & $0-5$ & $5-10$ & $10-20$ & $20-50$ & $50-100$ & $100-500$ & $500-1000$ & $>1000$ \\
\hline \multirow{3}{*}{ 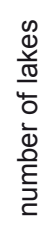 } & $\begin{array}{l}\text { With increasing water } \\
\text { resources }\end{array}$ & - & 3 & 3 & 2 & 3 & 12 & 1 & - \\
\hline & $\begin{array}{l}\text { With decreasing water } \\
\text { resources }\end{array}$ & - & - & 5 & 21 & 18 & 40 & 5 & 4 \\
\hline & $\begin{array}{l}\text { Without changes in water } \\
\text { resources }\end{array}$ & 1 & 1 & 1 & 6 & - & 1 & - & - \\
\hline
\end{tabular}

Table 3. Number of lakes in groups based on changes in surface and water resources

\begin{tabular}{|c|c|c|c|c|c|c|c|}
\hline \multirow{2}{*}{\multicolumn{2}{|c|}{$\begin{array}{c}\text { Water resources } \\
\text { changes [\%] }\end{array}$}} & \multicolumn{2}{|c|}{ Decreased } & \multirow{3}{*}{$\begin{array}{c}\text { "0" } \\
1\end{array}$} & \multicolumn{3}{|c|}{ Increased } \\
\hline & & \multirow{2}{*}{$\frac{50-25}{1}$} & \multirow{2}{*}{$\frac{25-0}{4}$} & & \multirow{2}{*}{$\frac{0-25}{1}$} & \multirow{2}{*}{$\begin{array}{c}25-50 \\
1\end{array}$} & \multirow{2}{*}{$\begin{array}{r}>50 \\
-\end{array}$} \\
\hline D్ర & $50-25$ & & & & & & \\
\hline ڤ్ర & $25-0$ & 12 & 52 & 6 & 9 & 3 & 1 \\
\hline \multicolumn{2}{|r|}{ „0" } & 1 & 3 & - & 1 & - & - \\
\hline \multirow{3}{*}{ 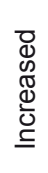 } & $0-25$ & 5 & 14 & 3 & 5 & 2 & 1 \\
\hline & $25-50$ & - & - & - & - & - & - \\
\hline & $>50$ & - & 1 & - & - & - & - \\
\hline
\end{tabular}

Table 4. Changes in lake capacity due to shallowing

\begin{tabular}{|c|c|c|c|c|}
\hline \multirow[b]{2}{*}{ Lake } & \multicolumn{2}{|c|}{1910} & \multicolumn{2}{|c|}{1960} \\
\hline & $\begin{array}{c}\text { Surface } \\
\text { [ha] }\end{array}$ & $\begin{array}{c}\text { Volume } \\
{\left[\mathrm{hm}^{3}\right]}\end{array}$ & $\begin{array}{c}\text { Surface } \\
\text { [ha] }\end{array}$ & $\begin{array}{c}\text { Volume } \\
{\left[\mathrm{hm}^{3}\right]}\end{array}$ \\
\hline Bochenek & 4.5 & 0.2 & 4.5 & 0.17 \\
\hline Dołgie Wlk. & 44.0 & 2.6 & 44.4 & 2.2 \\
\hline Dubie & 110.0 & 12.3 & 112.0 & 8.1 \\
\hline Grylewskie & 110.0 & 4.8 & 119.1 & 4.3 \\
\hline Kierskie Małe & 34.0 & 0.5 & 34.0 & 0.47 \\
\hline Lipno & 9.0 & 0.5 & 9.0 & 0.49 \\
\hline Łobez & 45.0 & 2.9 & 45.5 & 2.5 \\
\hline Miejskie & 67.0 & 6.7 & 68.7 & 6.5 \\
\hline
\end{tabular}

The surface of the first three lakes in Table 4 did not change over almost 50 years but their volume decreased by $5.9 \%$. During the studied period, the remaining lakes increased their area by $3.6 \%$, although their capacity decreased by a total of $19.5 \%$.
The shallowing occurred in entire basins and the rate of accumulation depended on sediment material, bank slope and dynamics of water in the lake. However, the most sensitive to the shallowing process are lake bays and shallow parts. A good example 
Table 1. Changes in lake surface and water resource

\begin{tabular}{|c|c|c|c|c|c|c|c|}
\hline \multirow[b]{2}{*}{$\mathrm{No}^{*}$} & \multirow[b]{2}{*}{ Lake name } & \multicolumn{3}{|c|}{$1910^{* *}$} & \multicolumn{3}{|c|}{$1960^{* * *}$} \\
\hline & & Surface & Volume & Altitude & Surface & Volume & Altitude \\
\hline & & [ha] & {$\left[\mathrm{hm}^{3}\right]$} & [m a.s.I.] & [ha] & {$\left[\mathrm{hm}^{3}\right]$} & [m a.s.I.] \\
\hline 18.89 & Białeckie & 38.0 & 1.0 & 39.7 & 34.1 & 0.8 & 39.7 \\
\hline 18.106 & Białkowskie & 153.0 & 13.3 & 83.1 & 145.9 & 14.0 & 83.1 \\
\hline 33.1 & Biezdruchowo & 49.0 & 3.6 & 96.0 & 48.8 & 2.8 & 97.0 \\
\hline 11.33 & Biskupińskie & 128.0 & 7.4 & 79.6 & 116.6 & 6.4 & 79.6 \\
\hline 43.8 & Bnińskie & 254.0 & 11.2 & 65.5 & 225.9 & 9.5 & 65.5 \\
\hline 29.44 & Bobowickie & 36.0 & 2.8 & 51.5 & 36.5 & 2.8 & 51.5 \\
\hline 42.6 & Bochenek & 4.5 & 0.2 & 70.8 & 4.5 & 0.2 & 70.8 \\
\hline 20.35 & Brzeźno & & $\mathrm{t}$ of Lake & & 24.3 & 0.4 & 74.2 \\
\hline 32.13 & Brzostek & 6.0 & 0.2 & 92.0 & 6.0 & 0.3 & 92.0 \\
\hline 53.66 & Bucierz Wlk & 154.0 & 20.8 & 98.0 & 150.2 & 15.9 & 98.5 \\
\hline 43.2 & Budzińskie & 19.0 & 0.2 & 61.4 & 17.4 & 0.3 & 61.4 \\
\hline 10.4 & Budziszewskie & 177.0 & 9.7 & 71.5 & 163.0 & 7.8 & 71.5 \\
\hline 3.38 & Bukowieckie & 56.0 & 2.9 & 79.0 & 41.4 & 1.9 & 79.0 \\
\hline 63.59 & Bytyń & 823.0 & 94.9 & 113.0 & 877.1 & 91.5 & 113.0 \\
\hline 18.49 & Chalinek & 17.0 & 0.5 & 38.0 & 15.1 & 0.4 & 36.7 \\
\hline 29.56 & Chłop & 225.0 & 19.8 & 53.7 & 227.8 & 20.5 & 53.7 \\
\hline 3.3 & Chodzieskie & 126.0 & 4.4 & 54.2 & 115.6 & 3.5 & 54.2 \\
\hline 18.103 & Chrzypskie & 323.0 & 18.9 & 44.9 & 304.3 & 18.6 & 44.9 \\
\hline 54.4 & Chudowo & 40.0 & 4.8 & 100.0 & 41.5 & 4.0 & 99.7 \\
\hline 45.34 & Ciemino & 264.0 & 20.5 & 142.0 & 241.7 & 14.3 & 142.0 \\
\hline 35.1 & Cięszęcino & 115.0 & 16.6 & 155.0 & 102.2 & 13.7 & 154.2 \\
\hline 29.3 & Cisie & 42.0 & 3.5 & 40.0 & 39.2 & 3.7 & 40.7 \\
\hline 54.55 & Czaplino & 98.0 & 11.0 & 133.0 & 108.3 & 13.3 & 133.0 \\
\hline 10.3 & Czarne & 24.0 & 1.3 & 72.0 & 27.8 & 1.9 & 72.0 \\
\hline 47.13 & Człuchowskie Wielkie & 202.0 & 22.2 & 158.0 & 158.7 & 20.8 & 157.8 \\
\hline 42.5 & Dębno & 25.0 & 1.9 & 71.0 & 25.1 & 1.7 & 71.3 \\
\hline 54.61 & Dołgie Wielkie & 44.0 & 2.6 & 137.0 & 44.4 & 2.2 & 136.7 \\
\hline 44.36 & Drawsko & 1862.0 & 357.0 & 128.0 & 1871.5 & 331.4 & 128.7 \\
\hline 71.59 & Dubie & 110.0 & 12.3 & 77.0 & 112.0 & 8.1 & 77.3 \\
\hline 10.15 & Durowskie & 161.0 & 13.5 & 78.1 & 143.7 & 11.3 & 78.1 \\
\hline 18.2 & Duże Dormowskie & 30.0 & 1.6 & 71.3 & 27.0 & 1.6 & - \\
\hline 11.36 & Gadowskie & 31.0 & 1.1 & 79.8 & 29.6 & 1.0 & 79.8 \\
\hline 12.1 & Gąsawskie & 108.0 & 5.8 & 79.9 & 99.0 & 5.7 & 79.8 \\
\hline 29.33 & Głębokie & 120.0 & 9.5 & 50.0 & 124.9 & 11.5 & 50.4 \\
\hline 18.8 & Gorzyńskie & 81.0 & 11.4 & 44.6 & 76.2 & 13.1 & - \\
\hline 3.37 & Grylewskie & 110.0 & 4.8 & 79.3 & 119.1 & 4.3 & 79.8 \\
\hline 42.18 & Jarosławskie & 10.0 & 0.3 & 76.3 & 11.2 & 0.4 & 76.3 \\
\hline 18.65 & Jaroszewskie & 96.0 & 12.5 & 39.0 & 92.2 & 13.0 & 38.3 \\
\hline 32.11 & Jerzyńskie & 46.0 & 2.9 & 94.5 & 38.9 & 2.1 & 94.5 \\
\hline 45.31 & Juchowo & 31.0 & 0.9 & 143.0 & 32.0 & 0.8 & 143.2 \\
\hline 54.45 & Kaleńskie & 113.0 & 16.4 & 140.0 & 106.2 & 12.2 & - \\
\hline 22.46 & Kamienickie & 284.0 & 25.0 & 85.6 & 232.5 & 20.3 & 85.6 \\
\hline 44.12 & Kamień & 23.0 & 1.3 & 143.0 & 35.8 & 1.1 & 130.4 \\
\hline 54.13 & Kańsko & 51.0 & 3.1 & 117.0 & 54.1 & 1.8 & 118.1 \\
\hline 31.14 & Kierskie & 310.0 & 34.1 & 71.9 & 210.0 & 34.1 & 71.9 \\
\hline 31.15 & Kierskie Mł. & 34.0 & 0.5 & 71.7 & 34.0 & 0.5 & 71.7 \\
\hline 10.16 & Kobyleckie & 68.0 & 5.1 & 78.7 & 65.7 & 4.8 & 78.7 \\
\hline 44.54 & Komorze & 492.0 & 62.0 & 131.0 & 416.7 & 49.3 & 131.1 \\
\hline 43.7 & Kórnickie & 87.0 & 3.0 & 65.3 & 81.9 & 2.1 & 65.3 \\
\hline 72.28 & Krępa & 29.1 & 1.6 & 75.0 & 19.4 & 1.0 & 72.5 \\
\hline 54.28 & Krosino & 190.0 & 14.8 & 123.0 & 177.2 & 12.7 & 123.0 \\
\hline 54.52 & Krzemienko & 18.0 & 1.6 & 140.0 & 17.3 & 1.2 & 140.1 \\
\hline 54.47 & Krzemno & 138.0 & 20.7 & 140.0 & 138.8 & 21.2 & 140.0 \\
\hline 18.66 & Kwileckie & 20.0 & 1.0 & 80.4 & 19.5 & 0.7 & 80.4 \\
\hline 21.7 & Lednica & 364.0 & 25.3 & 109.8 & 339.1 & 24.3 & 109.8 \\
\hline 42.8 & Lipno & 9.0 & 0.5 & 70.0 & 9.0 & 0.5 & 70.0 \\
\hline 45.7 & Lubicko Wielkie & 188.0 & 11.0 & 130.0 & 170.7 & 11.6 & 130.3 \\
\hline 54.1 & Lubie & 1485.0 & 203.0 & 95.0 & 1439.0 & 169.8 & 95.0 \\
\hline 17.13 & Lubikowskie & 340.0 & 37.5 & 54.6 & 314.7 & 34.8 & 54.6 \\
\hline 31.13 & Lusowskie & 148.0 & 11.8 & 79.6 & 121.9 & 10.4 & 79.6 \\
\hline 18.71 & Lutomskie & 174.0 & 8.7 & 37.6 & 172.7 & 11.6 & 37.6 \\
\hline 18.46 & Ławickie & 95.0 & 7.1 & 36.6 & 90.1 & 6.5 & 36.5 \\
\hline 11.2 & Łęknińskie & 88.0 & 1.4 & 84.8 & 85.2 & 1.3 & 84.8 \\
\hline 43.12 & Łękno & 27.0 & 0.8 & 67.1 & 26.1 & 0.5 & 67.7 \\
\hline 35.2 & Łobez & 45.0 & 2.9 & 154.0 & 45.5 & 2.5 & 154.2 \\
\hline 42.11 & Łódzko- Dym. & 137.0 & 7.3 & 64.7 & 119.6 & 6.2 & 64.7 \\
\hline 42.15 & Małe & 10.0 & 0.1 & 78.8 & 9.8 & 0.2 & 78.6 \\
\hline
\end{tabular}




\begin{tabular}{|c|c|c|c|c|c|c|c|}
\hline 29.55 & Miejskie & 67.0 & 6.7 & 57.0 & 68.7 & 6.5 & 57.0 \\
\hline 12.39 & Mielno & 203.0 & 5.9 & 75.3 & 179.0 & 3.7 & 75.0 \\
\hline 22.43 & Mogileńskie & 86.0 & 3.4 & 89.9 & 77.0 & 2.5 & 89.9 \\
\hline 44.13 & Niecino & 42.0 & 1.8 & 130.0 & 35.8 & 1.1 & 130.4 \\
\hline 31.9 & Niepruszewskie & 248.0 & 7.6 & 77.8 & 242.3 & 7.5 & 75.8 \\
\hline 12.2 & Oćwieckie & 151.0 & 15.7 & 81.9 & 142.7 & 12.9 & 81.9 \\
\hline 53.80 & Okra & 82.0 & 4.3 & 103.0 & 50.5 & 3.8 & 103.2 \\
\hline 80.48 & Osiek & 604.0 & 66.0 & 53.0 & 538.9 & 50.0 & 53.4 \\
\hline 22.24 & Ostrowickie & 281.0 & 22.4 & 99.6 & 276.7 & 22.9 & 99.6 \\
\hline 22.69 & Ostrowskie & 349.0 & 32.8 & 99.0 & 214.5 & 31.2 & 98.9 \\
\hline 29.21 & Paklicko Wielkie & 229.0 & 19.5 & 65.0 & 196.0 & 15.8 & 65.0 \\
\hline 54.42 & Piasecznik Wielkie & 41.0 & 3.3 & 133.0 & 45.4 & 2.9 & 133.0 \\
\hline 29.51 & Piechiewo & 17.0 & 0.5 & 51.3 & 18.0 & 1.3 & 54.5 \\
\hline 45.27 & Pile & 933.0 & 137.0 & 130.0 & 980.1 & 115.1 & 130.1 \\
\hline 18.9 & Płytkie & 13.0 & 0.3 & 72.2 & 11.5 & 0.4 & - \\
\hline 22.20 & Popielewskie & 313.0 & 41.3 & 96.0 & 308.5 & 38.2 & 96.0 \\
\hline 34.4 & Powidzkie & 1200.0 & 140.0 & 98.7 & 1174.7 & 134.7 & 98.3 \\
\hline 18.21 & Proboszczowskie & 17.0 & 0.5 & 34.0 & 15.0 & 0.5 & 33.0 \\
\hline 62.55 & Prostynia & 57.0 & 2.3 & 81.0 & 57.7 & 1.2 & 80.2 \\
\hline 18.50 & Puntik & 21.0 & 0.9 & 39.0 & 19.6 & 0.9 & 39.4 \\
\hline 51.31 & Raczyńskie & 79.0 & 2.6 & 68.0 & 84.4 & 2.3 & 68.9 \\
\hline 10.2 & Rogoźno & 136.0 & 5.2 & 69.5 & 125.8 & 3.8 & 69.7 \\
\hline 42.13 & Rosnowskie & 43.0 & 1.5 & 81.3 & 34.2 & 1.3 & 81.3 \\
\hline 12.36 & Sadłogoszcz & 57.0 & 0.7 & 75.2 & 43.0 & 0.6 & 75.2 \\
\hline 44.26 & Siecino & 776.0 & 111.4 & 129.0 & 729.1 & 104.4 & 129.0 \\
\hline 11.31 & Skarbińskie & 75.0 & 4.8 & 79.4 & 64.0 & 3.0 & 79.4 \\
\hline 20.45 & Skockie & 79.0 & 2.8 & 72.7 & 77.1 & 2.1 & 72.7 \\
\hline 34.1 & Skorzęcinskie & 748.0 & 43.9 & 104.0 & 637.7 & 35.1 & 104.0 \\
\hline 11.37 & Skrzynka & 29.0 & 2.7 & 79.7 & 27.9 & 2.4 & 79.8 \\
\hline 43.5 & Skrzyńksie Duże & 77.0 & 3.2 & 65.2 & 91.5 & 3.1 & 65.2 \\
\hline 43.6 & Skrzyńskie Małe & 20.0 & 0.7 & 65.1 & 17.4 & 0.6 & 65.1 \\
\hline 9.4 & Somołęskie & 27.0 & 2.6 & 59.0 & 29.0 & 2.5 & 59.0 \\
\hline 34.52 & Stepińskie & 45.0 & 5.6 & 139.0 & 36.7 & 3.1 & 140.1 \\
\hline 20.44 & Stęszewskie & 106.0 & 4.0 & 94.7 & 78.4 & 3.2 & 94.7 \\
\hline 17.22 & Stołuń & 23.0 & 1.8 & 55.3 & 21.3 & 1.7 & 55.3 \\
\hline 42.1 & Strykowskie & 372.0 & 16.7 & 73.0 & 305.3 & 13.6 & 73.7 \\
\hline 3.1 & Strzeleckie & 18.0 & 0.6 & 64.3 & 16.0 & 0.5 & 65.2 \\
\hline 32.1 & Strzeszyńskie & 32.0 & 2.7 & 76.6 & 32.0 & 2.7 & 76.6 \\
\hline 32.3 & Swarzędzkie & 90.0 & 2.5 & 70.9 & 93.7 & 2.1 & - \\
\hline 22.39 & Szydłowskie & 142.0 & 21.0 & 95.2 & 140.2 & 15.8 & 95.2 \\
\hline 18.54 & Śremskie & 122.0 & 25.2 & 39.0 & 117.6 & 23.7 & 39.3 \\
\hline 42.2 & Tomickie & 68.0 & 0.8 & 69.0 & 47.2 & 0.7 & 69.0 \\
\hline 45.44 & Trzesiecko & 293.0 & 18.8 & 134.0 & 295.1 & 16.0 & 130.2 \\
\hline 54.29 & Wąsosze & 308.0 & 8.5 & 125.0 & 326.4 & 11.3 & 124.1 \\
\hline 11.32 & Weneckie & 151.0 & 7.6 & 79.6 & 131.7 & 6.0 & 80.0 \\
\hline 10.7 & Wiatrowskie & 31.0 & 1.2 & 77.8 & 26.9 & 1.0 & 77.8 \\
\hline 22.36 & Wiecanowskie & 345.0 & 11.0 & 91.3 & 300.0 & 9.4 & 91.3 \\
\hline 34.11 & Wielatowo & 184.0 & 4.0 & 143.0 & 186.6 & 4.6 & 142.7 \\
\hline 45.53 & Wielimie & 1830.0 & 50.0 & 133.0 & 1754.6 & 40.1 & 132.7 \\
\hline 29.65 & Wielkie & 377.0 & 7.2 & 51.2 & 238.7 & 5.0 & - \\
\hline 43.10 & Wielkie Jeziory & 72.0 & 2.5 & 66.4 & 60.3 & 1.8 & 66.0 \\
\hline 42.3 & Wielkowiejskie & 35.0 & 0.6 & 70.9 & 35.0 & 0.6 & 70.9 \\
\hline 34.14 & Wierzchowo & 772.0 & 67.6 & 139.0 & 731.0 & 70.2 & 139.5 \\
\hline 66.37 & Więcborskie & 218.0 & 15.1 & 108.0 & 194.0 & 16.2 & 108.0 \\
\hline 54.31 & Wilczkowo & 304.0 & 27.5 & 123.0 & 300.4 & 23.3 & 123.0 \\
\hline 42.7 & Witobelskie & 106.0 & 3.6 & 64.8 & 105.0 & 5.5 & 64.8 \\
\hline 20.28 & Włókna & 107.0 & 4.0 & 74.2 & 74.4 & 2.4 & 74.2 \\
\hline 29.37 & Wyszanowskie & 33.0 & 1.0 & 59.0 & 28.9 & 0.8 & 59.0 \\
\hline 44.47 & Żerdno & 192.0 & 29.5 & 128.0 & 205.0 & 31.2 & 128.5 \\
\hline 4.8 & Żnińskie Duże & 458.0 & 32.5 & 78.7 & 431.6 & 29.4 & 78.0 \\
\hline 11.30 & Żnińskie Małe & 165.0 & 4.3 & 78.9 & 135.1 & 3.0 & 78.9 \\
\hline
\end{tabular}

Abbreviations

* numbers according to Choiński (2006)

** data from Schütze (1920), KJP (1954)

*** data IIF (Choiński 2006) 
is Lake Skorzęcińskie (Fig. 2). The $5 \mathrm{~m}$ isobath "withdrew" significantly, particularly in the isolated parts of the lake (Fig. 2). Major changes were also observed in the deeper part of the reservoir. The area marked by the $10 \mathrm{~m}$ isobath decreased and was divided into three smaller parts. This process could have been caused by sediment slipping on steep slopes, characteristic for a ribbon lake. It was particularly observed along the peninsula in the eastern part of the lake. A schematic diagram of this process is presented in Fig. 3. Over almost 50 years, the lake surface decreased by $14.8 \%$ and its capacity by $20.1 \%$.

Chrzypskie Lake is characterised by a different kind of bottom surface change (Fig. 4). The shore slope was not as steep as in the previous example. The movement of deposited sediments occurred due to

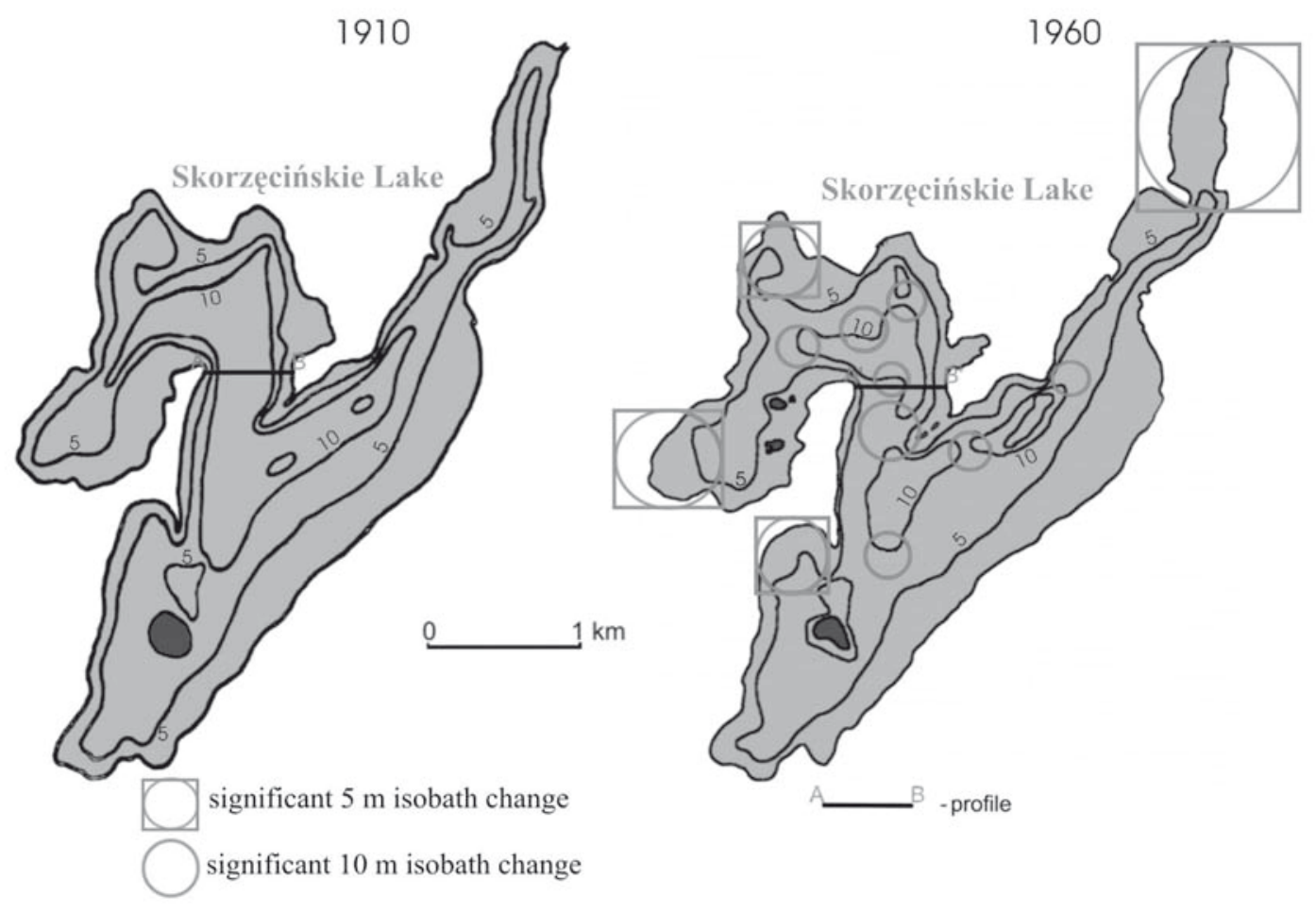

Fig.2. Bathymetry changes to Lake Skorzencińskie

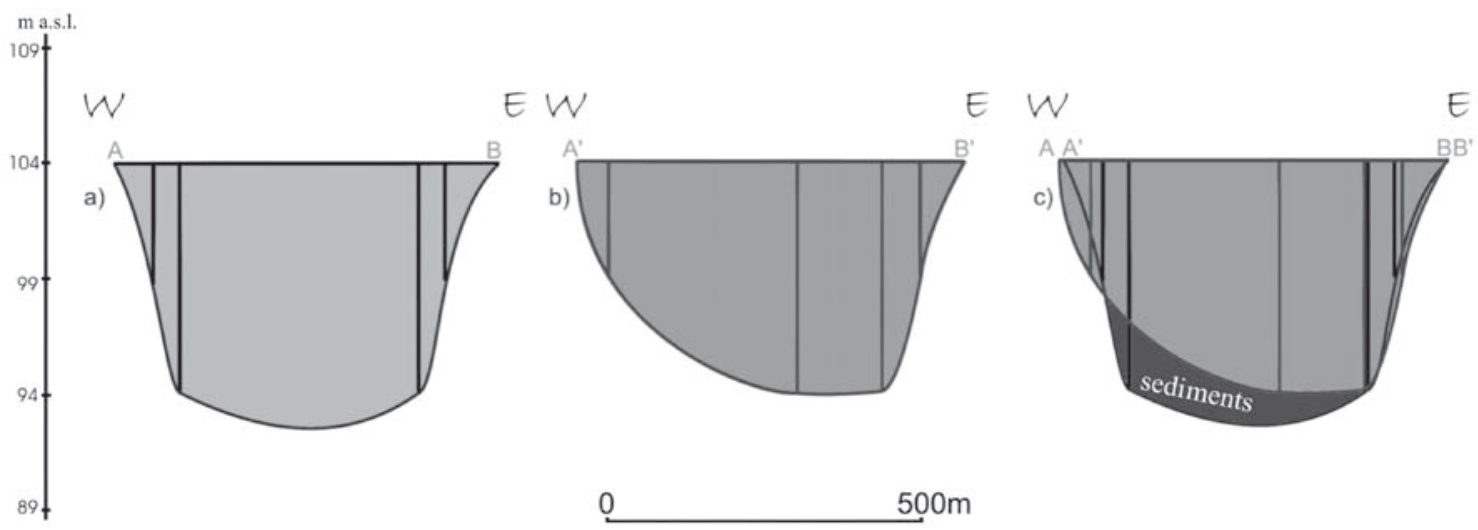

Fig.3. Cross section in a) 1910, b) 1960 and c) imposition of both profiles 


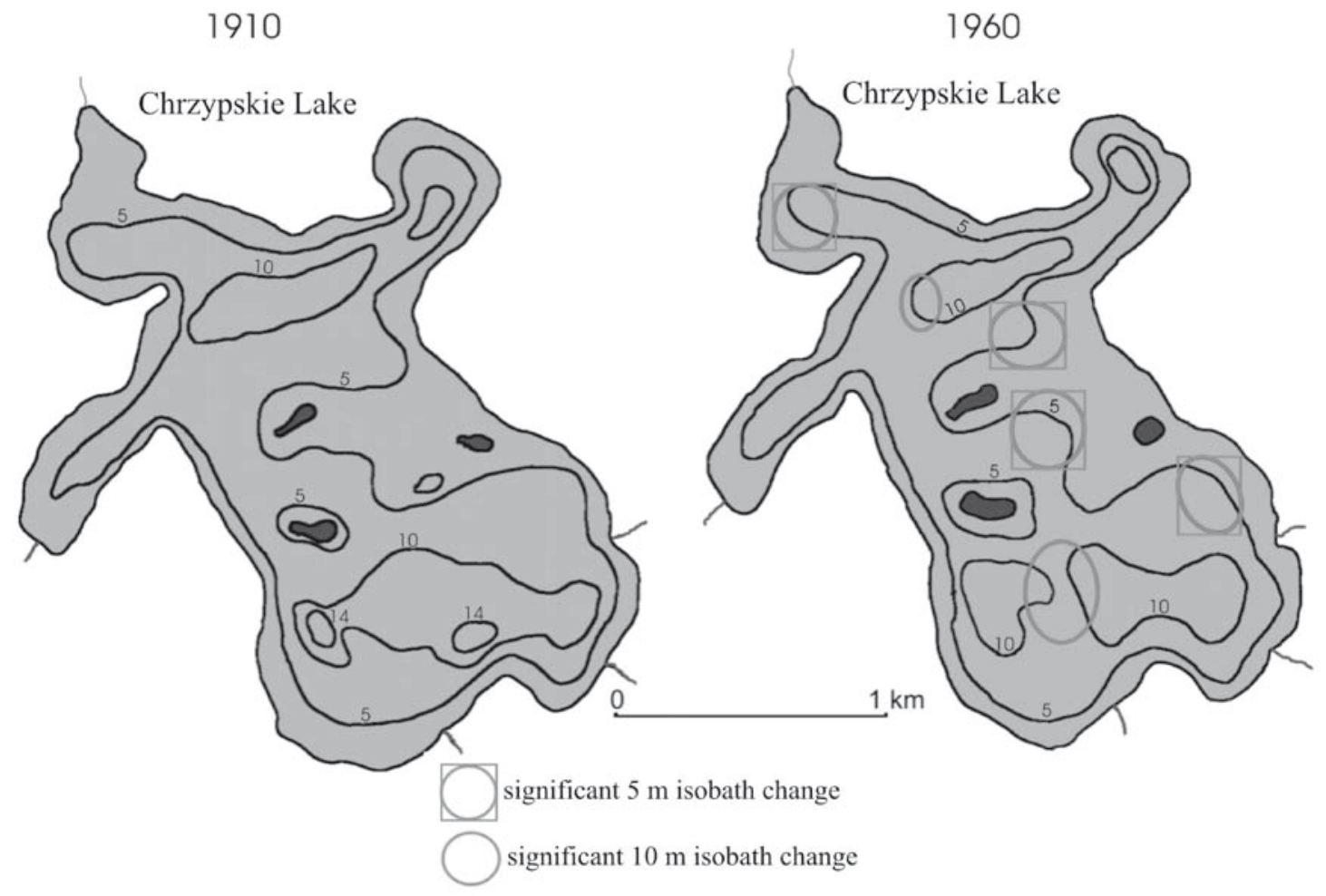

Fig.4. Bathymetry changes to Lake Chrzypskie

water transport properties, especially turbulent water movement induced by tributaries, wind, etc.

The role of tributaries in material loading and modelling processes of the lake bottom can be estimated on the basis of the $10 \mathrm{~m}$ isobath located in the southern part of the lake. This part of the lake was fragmented at the same level as the river inflow, with a simultaneous change in the outline of the area designated by this depth. However, the stable localisation of the $5 \mathrm{~m}$ isobath at the inflow of one of the tributaries is unclear, accompanied by simultaneous changes in further parts of the lake basin. These results indicated that river discharge reduced and lost its transport properties a significant distance from the inflow. In this part, intensive deposition of the transported material appeared. Lake Chrzypskie's surface decreased by $5.8 \%$ and its volume by $1.6 \%$ during the 50 -year study period.

\section{Conclusions}

The analyses of water resources showed a very unfavourable reduction in water capacity in the catchment of the River Warta. The disappearance of lakes occurred as a result of two parallel processes: shallow- ing and shrinking causing loss of water resources in the studied lakes over approximately 50 years by $10 \%$.

The discussed processes of disappearance of the analysed lakes could have been caused by farming intensification and nutrient loading from the catchment area. During the last decade, fertiliser application increased by $34.3 \%$ in Wielkopolska Voivodeship (USP 2001, 2010). Choiński (2007) and Choiński and Ptak (2009) hypothesised that changes in lake areas may be caused by intensive land improvement, particularly done during the 70s.

Our results indicated that the observed increase in water resources in some lakes was accelerated by an increase in lake areas. Hydrotechnic activities, consisting of water raising by damming in natural lakes for the purposes of increasing water resources can be effective only in the short-term perspective. Processes leading to the "filling" of lakes with organic material occur permanently, particularly in the lowest part in the catchment. Furthermore, the transformation of semi-aquatic or terrestrial environments to aquatic ones, as the result of an increase in water level, may accelerate the process of erosion and deposition of organic matter in the lake basin. 
One of the effective methods to increase water resources and reduce lake disappearance is sediment removal. However, this method is rarely used due to its high cost.

In order to reduce the rate of loss of water resources, it will be important to reduce nutrient loading to water bodies and to improve water quality in lakes and tributaries.

The obtained results indicated that one of the major processes causing lake disappearance is the invisible process of shallowing. This factor should be more strongly articulated in studies concerned with lake disappearance.

\section{References}

Antheunisse, A.M., 2007, Floodplain rehabilitation and the importance of nitrogen dynamics for plant communities [Dissertation], Utrecht University, Utrecht, p. 139.

Choiński, A., Ptak, M., 2009, Lake infill as the main factor leading to lake's disappearance, Pol. J. Environ. Stud. 18 (3): 347-352.

Choiński A., 1988, Zasobność wodna jezior polskich (Water resources of Polish lakes), Bad. Fizjogr. Pol. Zach. A 38, p .99 (in Polish).

Choiński A., 2002, Przykłady współczesnego zaniku jezior w Polsce (Examples of the contemporary disappearance of lakes in Poland), [in:] Ciupa T., Kupczyk E., Suligowski R. (eds.), Obieg wody w zmieniającym się środowisku (Water cycle in the changing environment), Pr. Inst. Geogr. AŚ 7: 1-15 (in Polish).

Choiński A., 2006, Katalog jezior Polski (Catalogue of Polish lakes), Wyd. Nauk. UAM, Poznań, p. 600 (in Polish).

Choiński A., 2007, Limnologia fizyczna Polski (Physical limnology of Poland), Wyd. Nauk. UAM, Poznań, p. 540 (in Polish).
Hu, Q., Feng, S., Guo, H., Chen G., Jiang, T., 2007, Interactions of the Yangtze river flow and hydrologic processes of the Poyang Lake, China J. Hydrol. 347(1-2): 90-100.

Jańczak J., 1984, Wstępna ocena zasobów wodnych jezior Polski (Preliminary assessment of the lake water resources), Czas. Geogr. 55(4): 441-451 50 (in Polish, English summary).

[KJP] Katalog jezior Polski (Catalogue of Polish lakes), 1954, PAN, Inst. Geogr., Dokum. Geogr., Warszawa (in Polish).

Ławniczak A. E., Choiński A., Kurzyca I., 2011, Dynamics of lake morphometry and bathymetry in various hydrological conditions, Pol. J. Environ. Stud. 20: 931-940.

Majdanowski S., 1954, Jeziora Polski (The lakes of Poland), Prz. Geogr. 26(2): 17-50 (in Polish, English summary).

Mikulski Z., 1965, Zarys hydrografii Polski (Outline of the hydrography of Poland), PWN, Warszawa, p. 288 (in Polish).

Müller B., Lotter A.F., Sturm M., Ammann A., 1998, Influence of catchment quality and altitude on the water and sediment composition of 68 small lakes in Central Europe, Aquat. Sci. 60: 316-337.

Pasquini A.I., Lecomte K.L., Depetris P. J., 2008, Climate change and recent water level variability in Patagonian proglacial lakes, Argentina, Global Planet. Change 63: 290-298.

Pfister L., Kwadijk J., Musy A., Bronstert A., Hoffmann L., 2004, Climate change, Land use 30 change and runoff prediction in the Rhine - Meuse basins, River Res. Appl. 20: 229-241.

[USP] Urząd Statystyczny w Poznaniu, 2001, Rocznik Statystyczny Województwa Wielkopolskiego (Statistical Yearbook Wielkopolskie Voivodship), Poznań, p. 378.

[USP] Urząd Statystyczny w Poznaniu, 2010, Rocznik Statystyczny Województwa Wielkopolskiego (Statistical Yearbook Wielkopolskie Voivodship), Poznań, p. 380.

Schütze H., 1920, Die Posener Seen, Forschungen zur deutschen Landes- und Volkskunde 22(2), p. 246.

Van Puijenbroek P.J.T.M., Janse J.H., Knoop J.M., 2004, Integrated modelling for nutrient loading and ecology of lakes in The Netherlands, Ecol. Model.174(1-2): 127-141. 